\title{
PANDEMI COVID-19 DALAM PERSPEKTIF DEMOGRAFI
}

( THE PANDEMIC OF COVID-19 IN DEMOGRAPHIC PERSPECTIVE)

\author{
Dwi Agus Styawan \\ BPS Kabupaten Kebumen \\ JL. Arung Binang No. 17 A, Kebumen \\ E-mail: dwi.agus@bps.go.id
}

\begin{abstract}
ABSTRAK
Covid-19 telah menjadi tantangan global yang berdampak pada berbagai sektor kehidupan. Kajian covid-19 dalam perspektif demografi sangat diperlukan sebagai dasar untuk mengetahui kelompok penduduk yang rentan terpapar covid-19. Penelitian ini bertujuan untuk mengkaji karakteristik demografi dan komorbiditas penduduk Indonesia terkonfirmasi positif covid-19. Sumber data penelitian ini adalah data sekunder yang berasal dari Gugus Tugas Percepatan Penanganan Covid-19 Indonesia. Penelitian ini menggunakan metode deskriptif dengan menganalisis grafik sesuai karakteristik demografi dan komorbiditas penduduk terkonfirmasi positif covid-19. Hasil penelitian menunjukkan bahwa laki-laki, berumur produktif, dan memiliki penyakit penyerta seperti hipertensi, diabetes mellitus, dan panyakit jantung merupakan kelompok rentan terpapar covid-19. Adapun penduduk laki-laki, berusia lanjut, dan memiliki penyakit penyerta beresiko lebih tinggi mengalami kematian akibat covid-19. Oleh karena itu, pemerintah hendaknya membatasi mobilitas penduduk terutama penduduk berumur produktif dan menerapkan protokol kesehatan secara ketat agar penularan covid-19 dapat dihentikan. Selain itu, pemerintah juga harus memberikan pelayanan kesehatan maksimal kepada penduduk lanjut usia yang terpapar covid-19 untuk menekan resiko kematian.
\end{abstract}

Kata kunci: Covid-19, Demografi, Komorbiditas.

\begin{abstract}
Covid-19 has become a global challenge that impacts various sectors of life. Covid-19 studies from a demographic perspective are very much needed as a basis for knowing which population groups are vulnerable to being exposed to Covid-19. This study aims to examine the demographic characteristics and comorbidity of the Indonesian population who are confirmed positive for Covid-19. The data source for this research is secondary data from the Task Force for the Acceleration of Handling Covid-19 in Indonesia. This study used a descriptive method by analyzing graphs according to the demographic characteristics and comorbidity of the population confirmed positive for covid-19. The results showed that men, of productive age, and having comorbidities such as hypertension, diabetes mellitus, and heart disease are a group prone to exposure to covid-19. The male population, who are elderly, and have comorbidities have a higher risk of dying from covid-19. Therefore, the government should limit the mobility of the population, especially those of productive age and strictly implement health protocols so that the transmission of covid-19 can be stopped. In addition, the government must also provide maximum health services to the elderly population who are exposed to Covid-19 to reduce the risk of death.
\end{abstract}

Keywords: Covid-19, Demography, Comorbidity.

\section{PENDAHULUAN}

Saat ini, Covid-19 telah menjadi tantangan global. Kasus positif Covid-19 pada awalnya hanya terjadi di Wuhan, China pada Desember 2019. Kini covid-19 telah menyebar ke 216 negara hingga pada 15 September 2020 tercatat sebanyak 29 juta kasus terkonfirmasi positif Covid-19 dengan angka kematian mencapai 925 ribu jiwa. Berdasarkan kawasan, Amerika merupakan kawasan dengan jumlah kasus terkonfirmasi positif covid-19 tertinggi yakni mencapai 14,9 juta orang. Kawasan dengan jumlah kasus terkonfirmasi positif tertinggi berikutnya adalah kawasan Asia Tenggara dan Eropa, masing-masing sebanyak 5,6 juta dan 4,8 juta orang. Adapun kawasan 
Afrika dan Pasifik Barat menjadi kawasan dengan jumlah kasus terkonfirmasi positif covid-19 relatif kecil, yakni masing-masing 1,1 juta dan 555 ribu orang (WHO, 2020).

Indonesia pertama kali mendeteksi keberadaan kasus covid-19 pada 2 Maret 2020 dengan jumlah 2 orang terkonfirmasi positif covid-19. Sejak itu, covid-19 menyebar begitu cepat hingga pada 17 September 2020 tercatat sebanyak 232.628 orang terkonfirmasi positif dengan angka kematian mencapai 9.222 jiwa (Gugus Tugas Percepatan Penanganan Covid-19, 2020). Pada awalnya, Kawasan Metropolitan Jabodetabek menjadi episentrum penyebaran Covid-19. Kini, covid-19 telah menjalar ke 34 Provinsi di Indonesia. Provinsi DKI Jakarta dan Jawa Timur merupakan provinsi dengan persentase kasus positif tertinggi, masing-masing sebesar 24,9 persen dan 17,3 persen. Adapun provinsi dengan persentase kasus positif terkecil adalah Provinsi Kepulauan Bangka Belitung, Sulawesi Tengah, dan Nusa Tenggara Timur masing-masing sebesar 0,1 persen atau tidak lebih dari 300 orang.

Pada satu sisi, sebanyak 71,6 persen atau sekitar 161 ribu orang di Indonesia telah sembuh dari covid-19. Akan tetapi pada sisi lain tren penurunan jumlah kasus terkonfirmasi positif Covid-19 di Indonesia relatif belum terjadi. Sebaliknya penambahan kasus positif baru terus terjadi di berbagai daerah. Bahkan, sejak 8 September 2020 penambahan kasus baru tercatat selalu lebih dari 3.000 kasus per hari dengan penambahan tertinggi terjadi pada 16 September 2020, yakni sejumlah 3.963 kasus. Hal ini menandakan bahwa penularan covid-19 masih berlangsung di tengah-tengah masyarakat. Selain itu penambahan kasus baru yang terus terjadi mengindikasikan belum disiplinnya masyarakat dalam menjalankan protokol kesehatan.

Pada dasarnya berbagai upaya telah dilakukan oleh pemerintah untuk menekan penyebaran covid-19. Salah satu upaya tersebut adalah penerapan karantina wilayah (lock down) atau dalam konteks Indonesia dikenal dengan Pembatasan Sosial Berskala Besar (PSBB). Penerapan PSBB ini sangat bergantung pada tingkat penyebaran covid-19 di setiap wilayah, baik provinsi ataupun kabupaten/kota berdasarkan penilaian dari Kementerian Kesehatan. Aturan pelaksanaan PSBB tersebut diatur melalui Peraturan Pemerintah (PP) Nomor 21 Tahun 2020 tentang Pembatasan Sosial Berskala Besar. Selain itu aturan mengenai PSBB juga diatur dalam Keputusan Presiden (Keppres) Nomor 11 Tahun 2020 tentang Penetapan Kedaruratan Kesehatan Masyarakat. PP dan Keppres tersebut ditandatangani Presiden Joko Widodo pada 31 Maret 2020.

Secara umum kebijakan PSBB diterapkan melalui pemberlakuan libur sekolah baik mulai pendidikan dasar hingga perguruan tinggi, penutupan tempat-tempat wisata/hiburan dan pusat perbelanjaan, pembatasan kapasitas penumbang transportasi publik, serta penerapan kebijakan bekerja dari rumah (work from home). Seluruh bentuk kebijakan ini tentu dibarengi dengan penerapan protokol kesehatan, yaitu penggunaan masker atau bahkan face shield, mencuci tangan dengan sabun, dan menjaga jarak baik secara fisik atau sosial. Berbagai bentuk kebijakan ini bertujuan untuk memutus rantai penyebaran covid-19, sehingga dapat menekan jumlah kasus terkonfirmasi positif covid-19 di Indonesia.

Namun, penerapan PSBB atau protokol kesehatan selama enam bulan ini belum berjalan optimal. Penambahan kasus baru masih berlangsung dan tren penurunan jumlah kasus positif belum terjadi. Hal ini tentu berdampak pada tersendatnya pembangunan di berbagai sektor, antara lain ekonomi, pendidikan, dan kesehatan. Dampak ini secara tidak langsung terlihat dari berbagai data yang telah dirilis oleh Badan Pusat Statistik (BPS). Pada triwulan kedua 2020, BPS mencatat bahwa pertumbuhan ekonomi Indonesia mengalami perlambatan sebesar 5,32 persen (BPS, 2020b). Selain itu, penerapan Pembatasan Sosial Bersakala Besar (PSBB) secara tidak langsung juga menyebabkan beberapa perusahaan berhenti berproduksi dan merumahkan para pekerjanya. Hal ini tercermin dalam hasil survei BPS terhadap 87.379 responden yang menyatakan bahwa terdapat 18,34 persen pekerj][a yang sementara dirumahkan dan 2,52 persen mengalami Pemutusan Hubungan Kerja (BPS, 2020a).

Berbagai dampak pandemi covid-19 harus segera diminimalkan dengan segera menekan jumlah kasus terkonfirmasi positif covid-19. Hal ini membutuhkan berbagai input data hasil kajiankajian ilmiah lintas sektoral atau perspektif. Salah satu perspektif kajian yang dapat digunakan adalah demografi atau kependudukan. Selama ini kajian-kajian mengenai pandemi covid-19 cenderung lebih banyak dari perspektif kesehatan atau epidemiologi, sedangkan perspektif demografi relatif belum banyak dikaji. Kajian dalam perspektif ini sangat penting untuk 
mengetahui kelompok rentan covid-19, sehingga nantinya upaya penanganan atau mitigasi lebih efektif dalam memutus penyebaran covid-19. Oleh karena itu penelitian ini mengisi kekosongan kajian tersebut dengan meneliti penyebaran covid-19 di Indonesia dari perspektif demografi. Secara umum penelitian ini memiliki tiga tujuan. Pertama penelitian ini bertujuan untuk mengkaji profil demografi penduduk Indonesia terkonfirmasi positif covid-19 berdasarkan jenis kelamin dan kelompok umur. Kedua, tujuan penelitian ini adalah mengkaji komorbiditas penduduk Indonesia terkonfirmasi positif covid-19.

\section{METODE}

Penelitian ini menjadikan Indonesia sebagai obyek kajian. Pilihan ini didasarkan pada demografi Indonesia sebagai salah satu negara dengan jumlah penduduk terbanyak di dunia. Selain itu dalam konteks pandemi covid-19, Indonesia merupakan salah satu negara di Asia dengan jumlah kasus terkonfirmasi positif yang relatif banyak. Sumber data penelitian ini adalah data sekunder yang berasal dari Gugus Tugas Percepatan Penanganan Covid-19 Indonesia. Kondisi data yang digunakan dalam penelitian ini adalah data per 2 Maret 2020 hingga 17 September 2020. Penelitian ini menggunakan metode deskriptif dengan menganalisis grafik hasil pengolahan data Gugus Tugas Percepatan Penanganan Covid-19 di Indonesia. Analisis grarfik bertujuan untuk mengkaji profil demografi dan komorbiditas penduduk Indonesia terkonfirmasi positif covid-19.

\section{HASIL DAN PEMBAHASAN}

\section{Karakteristik Demografi Penduduk Positif Covid-19 di Indonesia}

Pada kondisi 17 September 2020, tercatat sejumlah 232 ribu penduduk Indonesia yang terkonfirmasi positif covid-19. iKasus-kasus ini tersebar di 34 provinsi. DKI Jakarta dan Jawa Timur menjadi provinsi dengan jumlah kasus positif tertinggi di Indonesia, masing-masing sebesar 24,9 persen dan 17,3 persen. Adapun provinsi yang memiliki persentase terendah adalah Kepulauan Bangka Belitung, Sulawesi Tengah, dan Nusa Tenggara Timur masing-masing sebesar 0,1 persen atau tidak lebih dari 300 kasus (Gugus Tugas Percepatan Penanganan Covid-19, 2020).

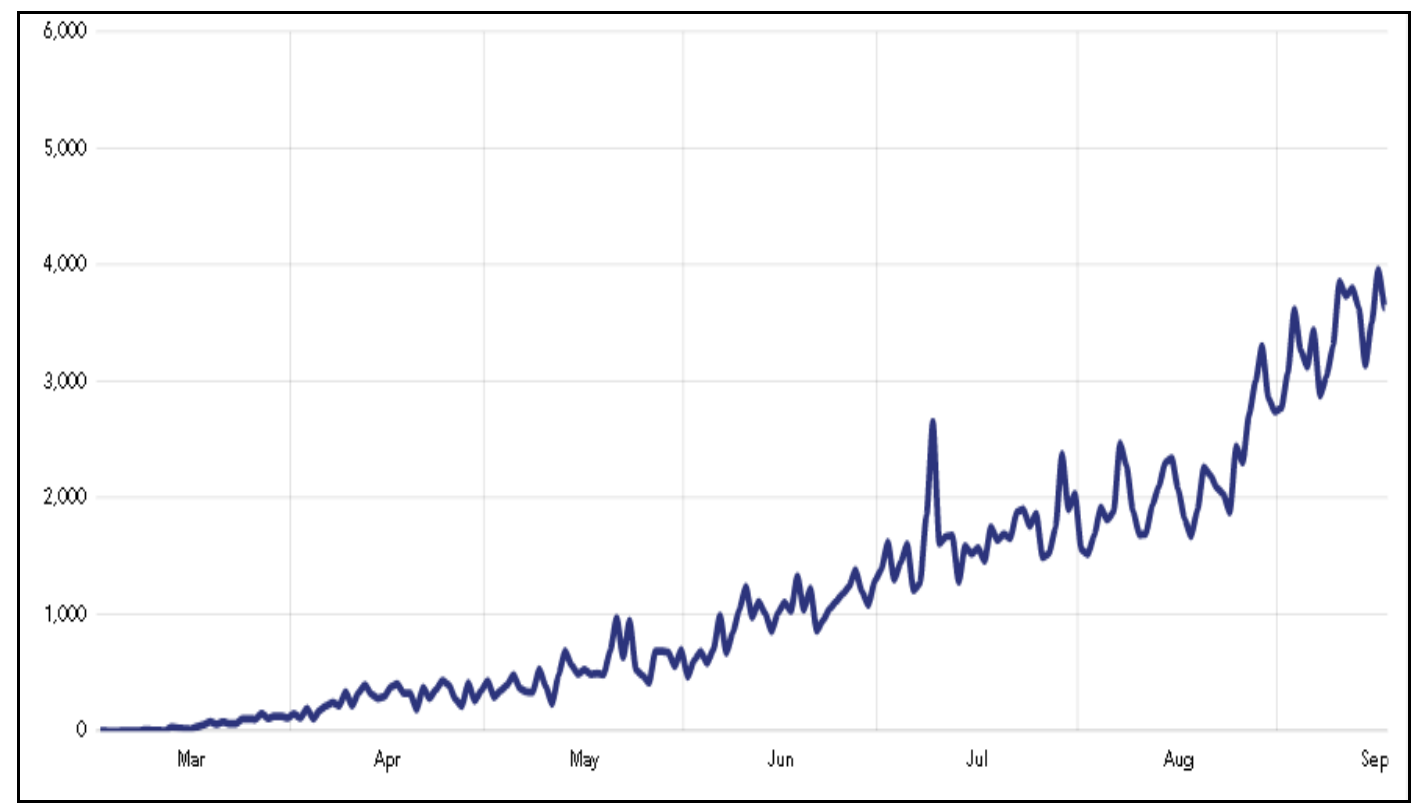

Grafik 22. Perkembangan Kasus Terkonfirmasi Positif Covid-19, Maret - September 2020. Sumber: Gugus Tugas Percepatan Penanganan Covid-19 (2020) 
Tren penurunan kasus terkonfirmasi positif covid-19 di Indonesia belum terjadi. Sebaliknya, penambahan kasus positif masih berlangsung. Bahkan selama sepekan terakhir rata-rata penambahan kasus mencapai 3.000 kasus per hari. Penambahan tertinggi terjadi pada 16 September 2020, yakni sebanyak 3.963 kasus (Grafik 1). Pernambahan kasus baru yang terus terjadi mengindikasikan bahwa penularan virus covid-19 masih berjalan di tengah masyarakat. Kondisi ini berlangsung seiring dengan berjalannya kembali aktivitas-aktivitas masyarakat, khususnya perkantoran, restoran/rumah makan, dan tempat wisata/hiburan. Kembali tingginya mobilitas penduduk menyebabkan covid-19 mendapatkan tempat untuk menyebar dengan lebih luas. Selain itu, kondisi ini juga menandakan bahwa kedisiplinan masyarakat dalam menjalankan protokol kesehatan dalam setiap aktivitas relatif belum baik.

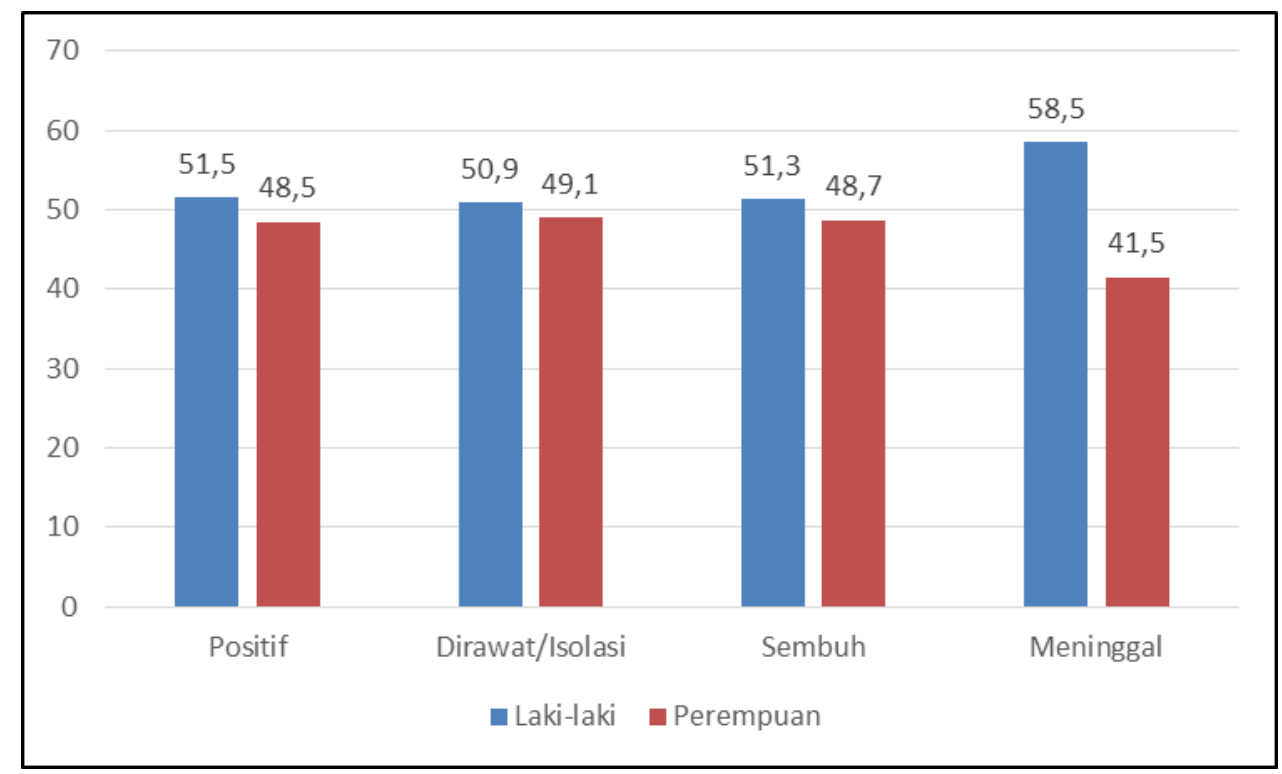

Grafik 2. Persentase Penduduk Positif Covid-19 berdasarkan Jenis Kelamin. Sumber: Gugus Tugas Percepatan Penanganan Covid-19 (2020)

Covid-19 menyerang setiap penduduk tanpa melihat batasan gender ataupun umur. Dalam konteks Indonesia, hasil analisis menunjukkan bahwa jumlah penduduk laki-laki terkonfirmasi positif covid-19 lebih banyak daripada perempuan (Grafik 2). Hal ini mengindikasikan laki-laki cenderung lebih rentan terpapar covid-19 dibandingkan dengan perempuan. Temuan ini sejalan dengan hasil penelitian lain yang juga menyimpulkan bahwa laki-laki memiliki resiko yang relatif lebih besar terpapar covid-19 daripada perempuan (Alon, Doepke, Rumsey, \& Tertilt, 2020; Biajibswas, 2020; Jin et al., 2020; Walter \& McGregor, 2020). Hal ini dimungkinkan karena mobilitas laki-laki cenderung lebih tinggi di luar rumah, sedangkan perempuan lebih banyak menghabiskan waktunya untuk pekerjaan-pekerjaan domestik rumah tangga. Selain itu, temuan ini juga sekaligus mengkonfirmasi bahwa terdapat perbedaan perilaku antara laki-laki dan perempuan dalam menjaga kesehatan dirinya. Perempuan cenderung lebih peduli dengan kesehatan dirinya dibandingkan dengan laki-laki (Gebhard, Regitz-Zagrosek, Neuhauser, Morgan, \& Klein, 2020). Hal inii tercermin pula dalam hasil survey yang diselenggarakan oleh Badan Pusat Statistik (BPS) bahwa selama masa pandemi perempuan cenderung lebih disiplin dalam menerapkan protokol kesehatan seperti memakai masker, mencuci tangan dengan sabun, dan menjaga jarak fisik/sosial (BPS, 2020a).

Grafik2 juga menghasilkan suatu temuan yang menarik bahwa pada satu sisi laki-laki lebih banyak yang berhasil sembuh dari covid-19, yakni 51,3 persen berbanding 48,7 persen. Akan tetapi pada sisi lain laki-laki memiliki resiko kematian akibat covid-19 yang lebih tinggi dibandingkan dengan perempuan. Bahkan persentase kematian laki-laki berbeda cukup signifikan dengan perempuan, yaitu 58,5 persen berbanding 41,5 persen. Kondisi ini dimungkinkan karena secara psikologis, laki-laki cenderung logis bahwa covid-19 dapat disembuhkan sehingga mereka memiliki semangat untuk sembuh yang cenderung lebih tinggi. Adapun perempuan cenderung lebih perasa dan mudah khawatir, sehingga secara psikis akan menganggu kesembuhannya dari 
covid-19. Sementara itu, tingginya resiko kematian laki-laki disebabkan oleh faktor biologis dan gaya hidup. Secara biologis, imunitas laki-laki cenerung lebih rendah daripada perempuan sehingga perempuan relatif lebih dapat bertahan dari hantaman virus covid-19. Selain itu gaya hidup laki-laki yang lebih banyak merokok menyebabkan mereka cenderung lebih banyak mengalami gangguan pernapasan, sehingga meningkatkan resiko kematian akibat covid-19 (Alon et al., 2020; Sharma, Volgman, \& Michos, 2020).

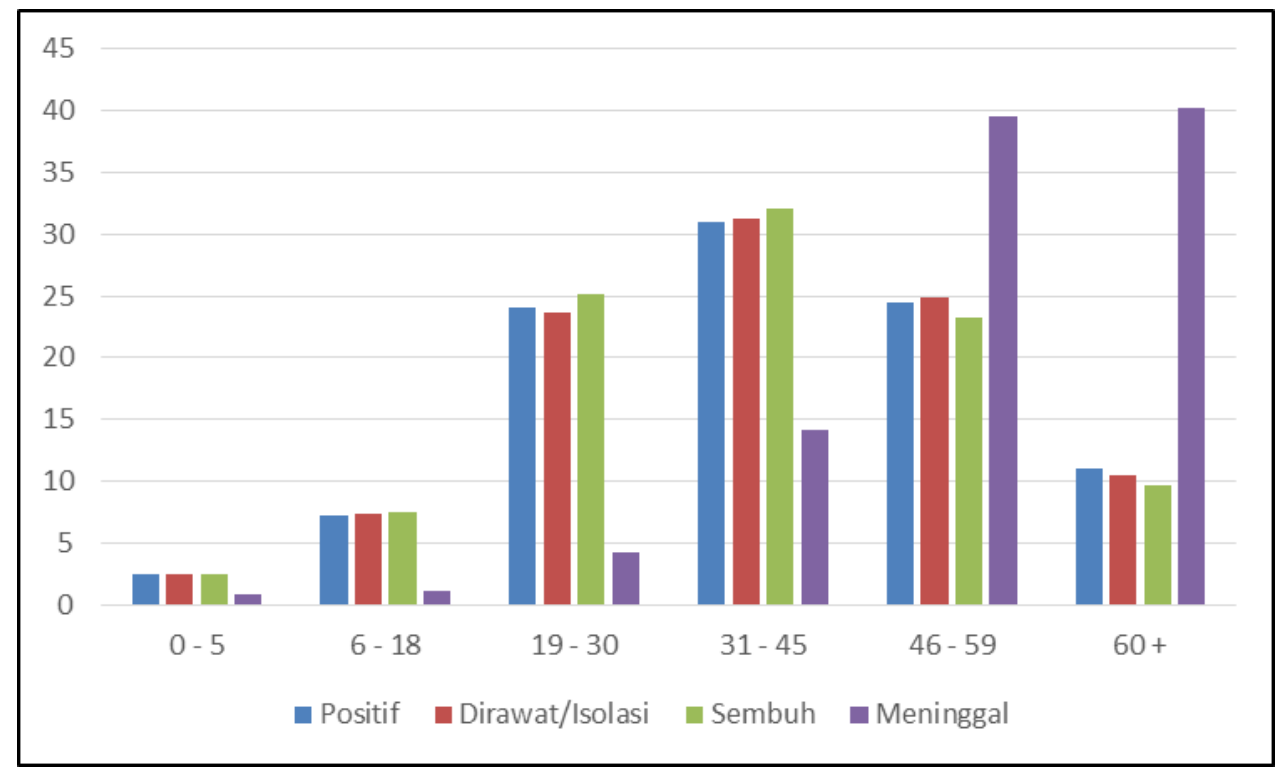

Grafik 3. Persentase Penduduk Positif Covid-19 berdasarkan Kelompok Umur. Sumber: Gugus Tugas Percepatan Penanganan Covid-19 (2020)

Hasil analisis berdasarkan kelompok umur, sebagaimana tersaji pada Grafik 3, juga memberikan temuan yang menarik. Kasus positif covid-19 di Indonesia lebih banyak dialami oleh penduduk berumur relatif muda yaitu 31 - 45 tahun, yakni sebesar 31 persen. Temuan ini menunjukkan bahwa kasus positif covid-19 di Indonesia didominasi oleh penduduk yang berumur produktif. Hal ini dimungkinkan karena mereka cenderung memiliki mobilitas yang tinggi, terutama untuk keperluan bekerja. Tingginya mobilitas ini menyebabkan penduduk berumur produktif lebih sering bersinggungan dengan orang luar dan bersentuhan dengan tempat-tempat publik, sehingga mereka lebih rentan terpapar covid-19. Temuan ini sejalan dengan penelitian-penelitian lain yang juga membuktikan bahwa penduduk berumur muda/produktif mendominasi kasus positif covid-19 (Cortis, 2020; Davies et al., 2020).

Hasil analisis kelompok umur juga menemukan bahwa kematian akibat covid-19 paling banyak ditemukan pada penduduk lanjut usia, yaitu penduduk yang berumur 60 tahun ke atas. Temuan ini mengindikasikan bahwa penduduklanjut usia memiliki resiko kematian yang lebih besar dibandingkan dengan kelompok umur lain. Hal ini disebabkan oleh faktor biologis dan kesehatan. Secara biologis, semakin bertambah umur seseorang maka imunitas akan semakin menurun. Kondisi ini mengakibatkan penduduk lanjut usia tidak memiliki daya tahan tubuh yang baik ketika terpapar covid-19 (United Nations, 2020). Adapun secara kesehatan, penduduk lanjut usia cenderung memiliki gangguan-gangguan kesehatan lain seperti jantung, paru-paru, diabetes melitus, dan hipertensi. Keberadaan penyakit-penyakit lain ini tentu akan semakin memperburuk kondisi penduduk lanjut usia positif covid-19, sehingga meningkatkan resiko kematian. Hasil penelitian ini juga senada dengan penelitian-penelitian lain yang menyimpulkan bahwa penduduk lanjut usia cenderung lebih rentan mengalami kematian akibat covid-19 (Guo et al., 2020; Kyriazis, 2020; Leung, 2020; Wang et al., 2020).

\section{Komorbiditas Penduduk Positif Covid-19 di Indonesia}

Pada dasarnya komorbiditas merupakan suatu kondisi dimana terjadi dua atau lebih penyakit yang berlangsung secara bersamaan, terlepas dari berkesinambungan atau tidaknya penyakit- 
penyakit tersebut (Valderas, Starfield, Sibbald, Salisbury, \& Roland, 2009). Adapun menurut Gulbech Ording \& Toft Sørensen (2013), komorbiditas merupakan suatu istilah untuk menunjukkan kondisi medis yang saling berkesinambungan atau terkait dengan kondisi atau penyakit lain dalam tubuh seorang pasien yang mengidap lebih dari satu penyakit. Dengan demikian komorbiditas adalah suatu kondisi pasien memiliki lebih dari satu penyakit yang terjadi bersamaan.

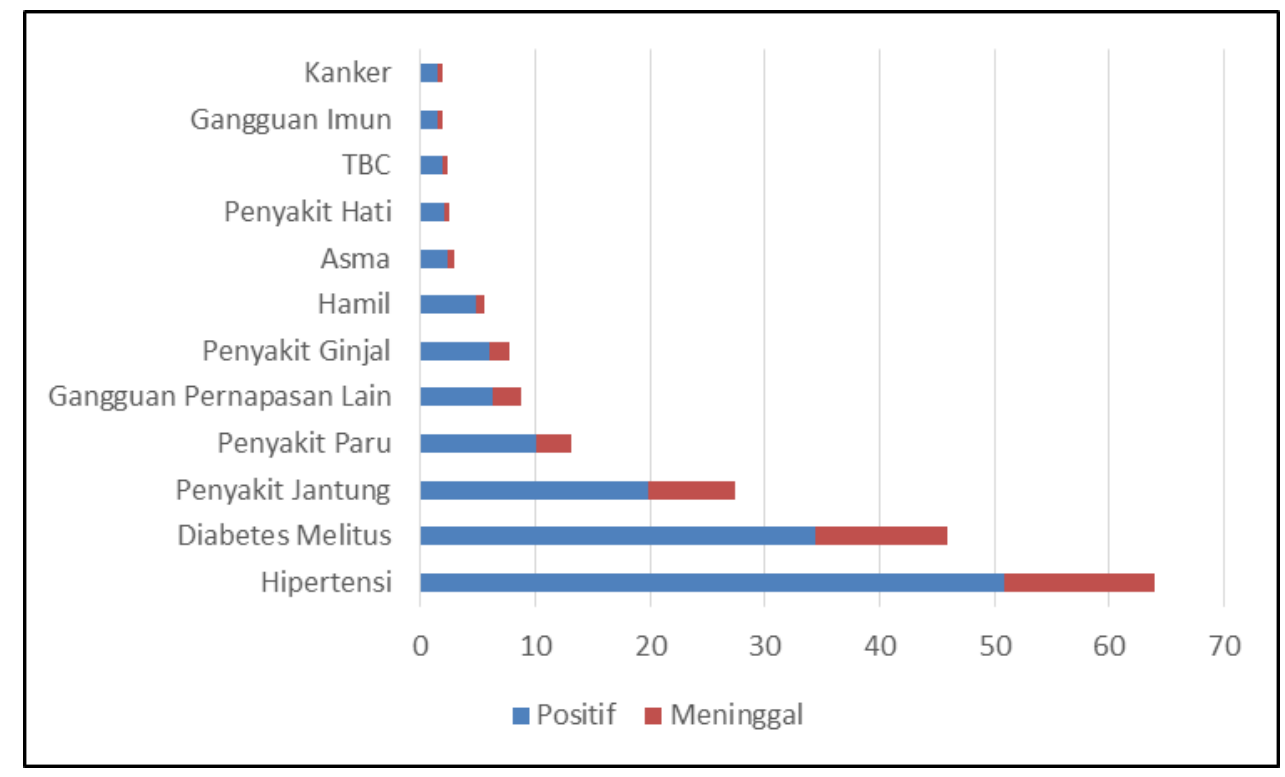

Grafik 4. Persentase Penduduk Positif Covid-19 berdasarkan Jenis Penyakit Penyerta. Sumber: Gugus Tugas Percepatan Penanganan Covid-19 (2020)

Hasil analisis komorbiditas, sebagaimana tersaji pada Grafik 4, menunjukkan bahwa hipertensi, diabetes melitus, dan penyakit jantung merupakan penyakit penyerta yang paling banyak dialami oleh penduduk terkonfirmasi positif covid-19. Hal ini disebabkan keberadaan tiga penyakit penyerta tersebut dapat menurunkan respon imun pasien sehingga lebih mudah terjangkit covid-19. Ketiga penyakit penyerta tersebut juga paling banyak dimiliki oleh penduduk yang meninggal akibat covid-19. Hal ini mengindikasikan bahwa penduduk yang memiliki penyakit bawaan seperti hipertensi, diabetes melitus, dan penyakit jantung memiliki resiko kematian yang cenderung lebih tinggi. Temuan ini sejalan dengan penelitian-penelitian terdahulu yang menyatakan bahwa seseorang yang memiliki penyakit penyerta lain lebih rentan terpaparcovid-19 dan memiliki resiko kematian yang relatif lebih tinggi (Galván-Tejada et al., 2020; Guan et al., 2020; Yang et al., 2020).

\section{KESIMPULAN}

Tren penurunan jumlah kasus terkonfirmasi positif covid-19 di Indonesia belum terjadi. Penularan covid-19 masih berlangsung di tengah masyarakat. Secara demografi, penduduk lakilaki, berumur produktif, serta memiliki penyakit penyerta seperti hipertensi, diabetes melitus, dan penyakit jantung merupakan kelompok rentan terpapar covid-19. Adapun resiko kematian akibat covid-19 paling banyak dimiliki oleh laki-laki, berusia lanjut, dan memiliki penyakit penyerta. Oleh karena itu, pemerintah hendaknya membatasi mobilitas penduduk terutama mereka yang berumur produktif dan melakukan pengawasan terhadap pelaksanaan protokol kesehatan secara ketat. Hal ini bertujuan untuk menghentikan penularan covid-19 dan menekan jumlah kasus positif covid-19. Selain itu, pemerintah juga harus memberikan pelayanan kesehatan maksimal kepada penduduk lanjut usia yang terpapar covid-19 untuk menekan resiko kematian. 
Alon, T., Doepke, M., Rumsey, J. O., \& Tertilt, M. (2020). The Impact of COVID-19 on Gender Equality (26947). Retrieved from https://doi.org/10.3386/w26947

Biajibswas. (2020). Are Men More Vulnerable to Covid-19 as Compared to Women? Biomed J Sci \& Tech Res, 272), 20645-20646. https://doi.org/10.26717/BJSTR.2020.27.004481

BPS. (2020a). Hasil Survei Sosial Demografi Dampak Covid-19. Jakarta: Badan Pusat Statistik.

BPS. (2020b). STATISTIK Pertumbuhan Ekonomi. Berita Resmi Statistik Pertumbuhan Ekonomi Indonesia Triwulan II-2020. Jakarta.

Cortis, D. (2020). On Determining the Age Distribution of COVID-19 Pandemic. Frontiers in Public Health, 8(May), 1-3. https://doi.org/10.3389/fpubh.2020.00202

Davies, N. G., Klepac, P., Liu, Y., Prem, K., Jit, M., Pearson, C. A. B., ... Eggo, R. M. (2020). Agedependent effects in the transmission and control of COVID-19 epidemics. Nature Medicine, 26(8), 1205-1211. https://doi.org/10.1038/s41591-020-0962-9

Galván-Tejada, C. E., Zanella-Calzada, L. A., Villagrana-Bañuelos, K. E., Moreno-Báez, A., LunaGarcía, H., Celaya-Padilla, J. M., ... Gamboa-Rosales, H. (2020). Demographic and comorbidities data description of population in mexico with SARS-CoV-2 infected patients(COVID19): An online tool analysis. International Journal of Environmental Research and Public Health, 1714), 1-17. https://doi.org/10.3390/ijerph17145173

Gebhard, C., Regitz-Zagrosek, V., Neuhauser, H. K., Morgan, R., \& Klein, S. L. (2020). Impact of sex and gender on COVID-19 outcomes in Europe. Biology of Sex Differences, 11(1). https://doi.org/10.1186/s13293-020-00304-9

Guan, W., Ph, D., Liang, W., Zhao, Y., Med, M., Liang, H., ... Liu, L. (2020). Comorbidity and its impact on 1,590 patients with COVID-19 in China: A Nationwide Analysis.

Gugus Tugas Percepatan Penanganan Covid-19. (2020). Peta Sebaran Covid-19 Indonesia. Retrieved from https://covid19.go.id/peta-sebaran

Gulbech Ording, A., \& Toft Sørensen, H. (2013). Concepts of comorbidities, multiple morbidities, complications, and their clinical epidemiologic analogs. Clinical Epidemiology, 5(1), 199-203. https://doi.org/10.2147/CLEP.S45305

Guo, T., Shen, Q., Guo, W., He, W., Li, J., Zhang, Y., ... Peng, H. (2020). Clinical Characteristics of Elderly Patients with COVID-19 in Hunan Province, China: A Multicenter, Retrospective Study. Gerontology, 410011(139), 1-9. https://doi.org/10.1159/000508734

Jin, J. M., Bai, P., He, W., Wu, F., Liu, X. F., Han, D. M., ... Yang, J. K. (2020). Gender Differences in Patients With COVID-19: Focus on Severity and Mortality. Frontiers in Public Health, 8(April), 1-6. https://doi.org/10.3389/fpubh.2020.00152

Kyriazis, M. (2020). COVID-19 Isolation and Risk of Death in Elderly People in Cyprus. Short Report - National Gerontology Centre, Cyprus, (April), 5-8. https://doi.org/10.13140/RG.2.2.23636.35206

Leung, C. (2020). Risk factors for predicting mortality in elderly patients with COVID-19: A review of clinical data in China, (January).

Sharma, G., Volgman, A. S., \& Michos, E. D. (2020). Sex Differences in Mortality From COVID-19 Pandemic. JACC: Case Reports, 2(9), 1407-1410. 
https://doi.org/10.1016/j.jaccas.2020.04.027

United Nations. (2020). Policy Brief: The Impact of COVID-19 on older persons. United Nations Sustainable Development Group, (May), 1-16.

Valderas, J. M., Starfield, B., Sibbald, B., Salisbury, C., \& Roland, M. (2009). Defining comorbidity: Implications for understanding health and health services. Annals of Family Medicine, 74), 357-363. https://doi.org/10.1370/afm.983

Walter, L. A., \& McGregor, A. J. (2020). Sex- And gender-specific observations and implications for COVID-19. Western Journal of Emergency Medicine, 21(3), 507-509. https://doi.org/10.5811/westjem.2020.4.47536

Wang, L., He, W., Yu, X., Hu, D., Bao, M., Liu, H., ... Jiang, H. (2020). Coronavirus disease 2019 in elderly patients: Characteristics and prognostic factors based on 4-week follow-up. Journal of Infection, 80(6), 639-645. https://doi.org/10.1016/j.jinf.2020.03.019

WHO. (2020). No Title. Retrieved September 16, 2020, from https://covid19.who.int/

Yang, J., Zheng, Y., Gou, X., Pu, K., Chen, Z., Guo, Q., ... Zhou, Y. (2020). Prevalence of comorbidities and its effects in coronavirus disease 2019 patients: A systematic review and meta-analysis. International Journal of Infectious Diseases, 94(March), 91-95. https://doi.org/10.1016/j.ijid.2020.03.017 